\title{
PENGEMBANGAN DESAIN INFORMASI DAN PEMBELAJARAN AKSARA JAWA MELALUI MEDIA WEBSITE
}

\author{
Dimas Fakhruddin ${ }^{1}$, Agus Sachari ${ }^{2}$, Naomi Haswanto ${ }^{3}$ \\ 1,2,3 Fakultas Seni Rupa dan Desain, Institut Teknologi Bandung \\ hellodimasf@gmail.com ${ }^{1}$, asachari@yahoo.com², naomidkv@yahoo.co.id ${ }^{3}$
}

\begin{abstract}
Abstrak
Aksara Jawa merupakan salah satu warisan budaya Indonesia, khususnya budaya masyarakat Jawa. Seiring dengan digunakannya huruf Latin sebagai sistem penulisan resmi, aksara Jawa perlahan mulai dilupakan oleh masyarakat, khususnya generasi muda. Upaya pelestarian dalam bidang pendidikan melalui mata pelajaran muatan lokal bahasa daerah pada jenjang sekolah, khususnya SMA dan sederajat, dirasa kurang dari segi alokasi waktu serta cara pembelajaran yang cenderung masih monoton. Untuk menanggulangi hal itu, dibutuhkan sebuah desain informasi yang bisa dimanfaatkan sebagai sarana pembelajaran aksara Jawa. Untuk mencapai hal tersebut, terlebih dahulu dilakukan proses penelitian dengan menggunakan pendekatan etnografi yang berangkat dari fenomena aksara Jawa yang ada di masyarakat. Proses pengumpulan data dilakukan dengan cara observasi, studi literatur, dan wawancara etnografi. Kemudian dilakukan analisa anatomi aksara Jawa untuk mendeskripsikan elemen-elemen aksara Jawa sesuai dengan terminologi yang relevan dengan konteks tipografi yang berlaku di Indonesia. Data tersebut menjadi dasar dalam perancangan desain informasi aksara Jawa yang berisi informasi tentang sejarah, ragam bentuk aksara, dan cara penulisannya yang ditampilkan melalui media website dengan nama "Hanacara". Hasil uji coba yang telah dilakukan menunjukkan bahwa dari aspek visual, komunikasi, pembelajaran, dan apresiasi, website "Hanacara" merupakan solusi yang efektif sebagai media alternatif untuk mengenal dan mempelajari aksara Jawa.
\end{abstract}

Kata kunci: aksara Jawa, desain informasi, website

\begin{abstract}
Javanese script is considered as one of many of Indonesia's cultural heritage, especially Javanese culture. Due to the application of Latin script as the official writing of the country, Javanese Script slowly began to be forgotten by people, especially the younger generations. The effort to preserve through educational system by establishing the lesson of Local Content includes the Local-Vernacular Language in school, especially High school and equivalent, is considered lack in terms of time-framing and the monotonous method of teaching. To aim the goal, the writer started with conducting research using ethnography approach taken from the phenomenon of Javanese Script in the community. Observation, literature studies and ethnographic interviews were carried out as the process of gathering the data. Furthermore, the anatomical analysis of the Javanese Script's typography is applied to describe the element of Javanese Script based on the relevancy of its terminology and typography context that prevails in Indonesia. This data becomes the basis in creating the information design of Javanese Script that would be able to give information regarding history, the variety of script forms, and how to write the letters displayed through the website with the name "Hanacara". The test process was once held, and the result shows that by the aspect of visual, communication, learning, and appreciation, the website "Hanacara" is considered as the effective solution so as the alternative media to know and to learn Javanese Script.
\end{abstract}

Keywords: information design, Javanese script, website 


\section{PENDAHULUAN}

Manusia sebagai makhluk sosial tidak bisa terlepas dari kehidupan bermasyarakat. Interaksi antar manusia di dalam suatu tatanan masyarakat mampu membentuk sebuah kebudayaan yang akhirnya berkembang menjadi sebuah peradaban. Kebudayaan merupakan gaya hidup dari suatu kelompok masyarakat yang mencakup segala perilaku yang dipelajari oleh individu sebagaimana diharapkan oleh kelompok tersebut (Kusumohamidjojo, 2009). Terlepas gaya hidup yang dimaksud adalah gaya hidup primitif atau modern, kebudayaan tersebut pada akhirnya akan diwariskan dari satu generasi ke generasi berikutnya.

Salah satu cara untuk mewariskan sebuah kebudayaan kepada generasi selanjutnya adalah dengan menulis. Nicolete Gray dalam bukunya "A History of Lettering" (1986), menyatakan bahwa menulis merupakan kemampuan menggunakan tanda-tanda yang terlihat untuk memudahkan kita menyampaikan, menerima pesan dari dan ke orangorang yang terpisah satu sama lain oleh ruang, waktu, maupun keduanya. Sanusi (2010) berpendapat jika aksara merupakan rumah bagi bahasa, lewat aksara manusia bisa mencatat dan lewat aksara pula sejarah dituliskan dan dimulai (Widyatmoko et al., 2010). Berbagai jenis tulisan atau aksara berkembang di seluruh dunia dari masa ke masa sesuai dengan keadaan sosial, ekonomi, dan teknologi yang sedang berlaku.

Indonesia sebagai negara yang kaya akan ragam budaya, memiliki begitu banyak ciri khas tertentu pada tiap sukunya, termasuk di dalamnya budaya berbahasa. Dari sekian banyak ragam bahasa yang berlaku di Indonesia (lebih dari 500 ragam bahasa), hanya beberapa dari ragam bahasa tersebut yang memiliki aksara tersendiri. Salah satunya adalah suku Jawa dengan bahasa Jawa dan aksara Jawanya.

Di dalam budaya Jawa, aksara Jawa yang berfungsi sebagai sistem penulisan masyarakat terdahulu telah mengalami berbagai perubahan hingga bentuk yang sekarang dikenal sebagai Hanacaraka atau Carakan. Aksara Jawa adalah pengembangan dan modifikasi dari aksara Kawi. Sementara aksara Kawi merupakan pengembangan dan modifikasi dari aksara Palawa sebagai aksara pertama yang masuk ke wilayah Indonesia. Sama seperti aksara pendahulunya, aksara Jawa masuk dalam jenis aksara 'abugida', yaitu aksara yang dapat diikuti oleh penanda vokal untuk merubah bunyi vokal dasar. Aksara Jawa juga bersifat silabik (kesukukataan) karena tiap huruf mewakili minimal dua huruf dalam huruf latin (konsonan dan vokal).

Penggunaan aksara Jawa sudah dimulai sejak masa Kesultanan Mataram (abad ke-17) tetapi artefaknya baru ditemukan pada abad ke-19. Di lingkungan keraton, aksara Jawa banyak digunakan untuk menuliskan naskah-naskah Jawa kuno dalam bentuk kitabkitab, tembang-tembang Jawa, prasasti-prasasti, atau dalam surat-menyurat di kalangan istana dan urusan-urusan kerajaan (Yayasan Harapan Kita, 1997). Penggunaan aksara Jawa tidak hanya terpusat di lingkungan keraton saja, namun juga digunakan di seluruh lingkungan masyarakat Jawa pada waktu itu, termasuk di daerah pesisir maupun pegunungan. 
Pelestarian aksara Jawa menjadi hal yang perlu diperhatikan. Bukan hanya sebagai ciri khas budaya Jawa, melainkan juga sebagai bagian dari identitas masyarakat Jawa itu sendiri. Seperti halnya bentuk tradisi budaya Jawa lainnya yang sarat akan makna filosofis, aksara Jawa juga memiliki filosofi dan maknanya sendiri. Pemaknaan aksara Jawa secara filosofis telah banyak dilakukan, sekurang-kurangnya terdapat 20 versi penafsiran (Widyatmoko et al., 2010). Makna filosofi yang terkandung tak lepas dari kecenderungan filsafat Jawa yang membahas tentang kehidupan manusia sebagai makhluk Tuhan maupun manusia di dalam tatanan kehidupan sosial. Penafsiran seperti ini dapat ditemukan di dalam naskah-naskah peninggalan masa lalu seperti "Serat Sastra Gendhing" (Sultan Agung) dan "Serat Saloka Jiwa" (R.Ng. Ranggawarsita) (Ahmadi, 2002).

Sebagai langkah awal untuk melestarikan kembali aksara Jawa, pemerintah daerah sebenarnya telah melakukan upaya pelestarian dan pengenalan aksara Jawa sejak dini. Upaya tersebut berupa pembelajaran aksara Jawa yang terintegrasi dengan mata pelajaran Bahasa Jawa yang menjadi mata pelajaran wajib dalam muatan lokal. Sebagai contoh, Peraturan Gubernur Jawa Timur Nomor 19 Tahun 2014 tentang mata pelajaran bahasa daerah sebagai muatan lokal wajib di sekolah/madrasah, mulai dari tingkat Sekolah Dasar (SD), Sekolah Menengah Pertama (SMP)/Madrasah Tsanawiyah (MTS), hingga Sekolah Menengah Atas (SMA)/Sekolah Menegah Kejuruan (SMK)/Madrasah Aliyah (MA). Namun hal ini masih dirasa kurang karena alokasi waktu yang diberikan untuk mata pelajaran bahasa Jawa hanya 1-2 jam per minggu, dan tidak semua SMA/SMK/MA memasukkan mata pelajaran bahasa Jawa sebagai salah satu mata pelajaran wajibnya.

Selain melalui muatan lokal, usaha aktualisasi aksara Jawa di dalam kehidupan seharihari banyak ditemui dalam bentuk papan nama jalan, seperti yang ditemukan di wilayah Yogyakarta. Namun kenyataannya, banyak ditemukan kesalahan penulisan aksara Jawa pada papan nama jalan tersebut. Seperti yang dijelaskan oleh Fajar Wijanarko (wawancara pada 19 Oktober 2017), kurator manuskrip Museum Negeri Sonobudoyo Yogyakarta, pembuatan papan nama jalan tersebut dibuat oleh vendor ketiga yang belum begitu paham penulisan aksara Jawa secara digital dengan menggunakan typeface aksara Jawa yang telah banyak tersedia. Hal ini patut disayangkan, mengingat sebenarnya telah ada pedoman penulisan aksara Jawa yang dikeluarkan oleh Yayasan Pustaka Nusatama sesuai dengan Surat Keputusan Tiga Gubernur Jawa Tengah, D.I. Yogyakarta, serta Jawa Timur pada tahun 2002.

Mempelajari kembali aksara Jawa secara seksama, tentu akan sangat penting untuk menghindarkan karut-marutnya penulisan-penulisan bahasa Jawa dalam aksara Latin, seperti yang berserak di kalangan masyarakat Jawa, baik dari kalangan elit, sebagian akademisi, para jurnalis, maupun masyarakat Jawa pada umumnya (Prasaja, 2015). Lebih lanjut lagi, dengan mempelajari aksara Jawa secara seksama, akan membantu untuk memahami makna-makna filosofis sebagai representasi identitas masyarakat Jawa yang terkandung di dalam aksara Jawa itu sendiri maupun yang terkandung di dalam naskah-naskah peninggalan masa lalu. Karena jika hanya mengandalkan cara-cara 
pelestarian masa lalu, dikhawatirkan eksistensi aksara Jawa akan hilang dan tidak dikenali lagi.

Menanggapi permasalahan tersebut, diperlukan sebuah inovasi yang dapat membungkus informasi tentang aksara Jawa menjadi lebih menarik dan lebih kekinian. Sebagai langkah awal, dilakukan terlebih dahulu studi pustaka terhadap karya-karya penelitian terdahulu yang relevan dengan tema yang diangkat oleh penulis. Beberapa penelitian tersebut diantaranya, "Rancang Bangun Aplikasi Pembelajaran Aksara Jawa Berbasis Android" oleh Hambali, Sunarto, dan Sutanto (2013) yang menghasilkan aplikasi pembelajaran aksara Jawa melalui media smartphone berbasis Android untuk siswa kelas 3-6 SD. Kemudian "Perancangan dan Implementasi Sistem Pembelajaran Aksara Jawa untuk SD Berbasis Multimedia Di SDN Bumirejo 02" oleh Hakim dan Purnama (2012) yang menghasilkan media pembelajaran aksara Jawa berbasis multimedia untuk anak SD dengan mengkombinasikan teks, suara, animasi dan permainan. Terakhir, Yohanes, Robert, dan Nugroho (2017) melalui penelitiannya berjudul "Sistem Penerjemah Bahasa Jawa-Aksara Jawa Berbasis Finite State Automata" berhasil membuat sebuah website yang memiliki fitur transliterasi aksara Jawa ke dalam huruf latin dan sebaliknya.

Hasil analisa dari penelitian terdahulu tersebut dijadikan acuan dalam proses perancangan desain informasi aksara Jawa bentuk media digital yang mampu memberikan pengetahuan dasar aksara Jawa, baik dari segi bentuk aksara, berbagai macam variannya, cara penulisan, serta makna filosofis yang terkandung di dalamnya dirasa merupakan bentuk teknologi yang bisa dimanfaatkan. Dengan memanfaatkan teknologi ini diharapkan bisa menjadi sebuah solusi efektif untuk lebih melestarikan dan mengenalkan kembali aksara Jawa kepada generasi muda. Sehingga dapat menumbuhkan kembali kecintaan mereka terhadap budaya Jawa, yang pada akhirnya dapat memperkuat akar identitas sebagai masyarakat Jawa dan juga memantapkan jati diri sebagai bangsa Indonesia. Menimbang kekayaan budaya dari segi aksara daerah yang dapat digali di berbagai daerah di Indonesia, penelitian ini dapat dijadikan contoh perancangan berbasis riset terhadap aksara daerah lainnya di Indonesia.

\section{METODE PENELITIAN}

Penelitian ini merupakan proyek pengembangan desain informasi dengan menggunakan pendekatan etnografi yang berangkat dari masalah yang hadir di masyarakat tentang keberadaan aksara Jawa yang semakin ditinggalkan. Rangkaian penelitian ini mencakup dua tahap, yaitu tahapan penelitian dan perancangan.

Tahapan penelitian mencakup proses pengumpulan data hingga analisis data. Pengumpulan data dalam penelitian ini dilakukan dengan studi literatur, observasi, dan wawancara etnografi dengan narasumber. Narasumber terdiri atas kurator manuskrip aksara Jawa dan desainer font aksara Jawa. Hasil pengumpulan data kemudian dianalisis untuk dijadikan dasar acuan dalam proses perancangan. Data terkait aksara Jawa yang dihasilkan, dianalisis sesuai dengan teori tipografi sehingga didapatkan elemen-elemen dalam tiap aksaranya. Teori yang dipakai adalah anatomi huruf, yang menyebutkan 
bahwa seperti halnya manusia, huruf memiliki berbagai organ yang berbeda. Gabungan seluruh elemen dari sebuah bentuk huruf merupakan identitas visual yang dapat membedakan antara huruf yang satu dengan huruf yang lain (Sihombing, 2017).

Tahapan perancangan desain informasi aksara Jawa dimulai dengan merancang mind mapping dan pembuatan sketsa keseluruhan halaman website sebagai media terpilih. Kemudian dilakukan perancangan aset visual yang terdiri dari aset halaman website, konten aksara Jawa, dan panduan cara penulisan aksara Jawa. Seluruh sistem desain grafis dalam website dirancang sedemikian rupa sehingga nilai khas dari visual aksara Jawa tetap dapat dimunculkan dengan sentuhan masa kini.

Berikut skema kerangka studi pustaka dan landasan teori yang digunakan dalam perancangan ini:

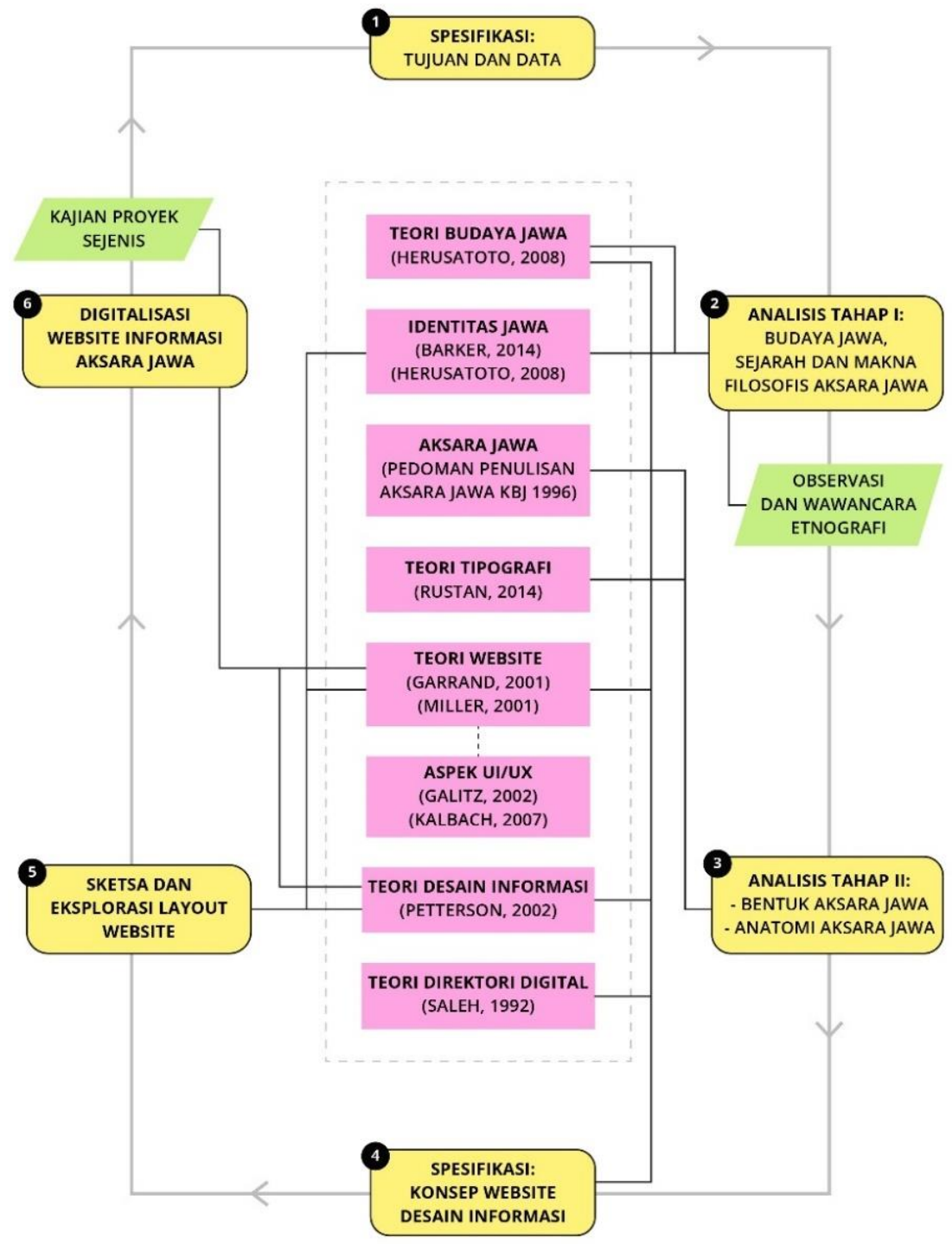

Gambar 1. Kerangka studi pustaka dan landasan teori

[Sumber: Dokumentasi penulis] 


\section{HASIL DAN PEMBAHASAN}

\subsection{Aksara Jawa}

Perkembangan aksara Jawa hingga menemukan bentuknya seperti yang sekarang ini merupakan hasil dari sebuah proses akulturasi budaya yang sangat panjang. Dimulai dari proses adaptasi aksara Palawa dengan budaya lokal yang terjadi di berbagai daerah, tak hanya di Pulau Jawa, yang melahirkan aksara Kawi. Seperti ditemukannya prasasti yang menggunakan aksara Kawi dengan gaya Sumatera yang kuat pada prasasti Raja Sriwijaya, Kedukan Bukit, Talang Tuo, Kota Kapur, Karang Berahi, Palas Pasemah dan Prasasti Jabung.

Selanjutnya, aksara Kawi tersebut mengalami perbuahan bentuk yang lebih tipis dan lebih pipih pada sekitar abad $14 \mathrm{M}-15 \mathrm{M}$, seperti yang ditemukan pada prasasti Kebantenan. Tapi kemudian berubah bentuk menjadi lebih membulat diperkaya dengan lekukan di seluruh batang tubuh aksara yang dipakai. Jenis aksara ini dipakai hingga abad $16 \mathrm{M}$, yang kemudian berangsur berubah menjadi lebih pipih dan kaki aksara yang lebih merapat (Yayasan Harapan Kita, 1997).

Hal ini menandakan banyaknya variasi aksara yang terjadi disebabkan bukan hanya karena budaya suatu kelompok tertentu, namun juga faktor geografisnya juga berpengaruh. Seperti halnya bentuk aksara di daerah pesisir Jawa dengan bentuk aksara di daerah pegunungan, memliki bentuk aksara yang berbeda walaupun masih termasuk satu induk yaitu aksara Kawi.

Perubahan aksara Palawa yang terjadi di Pulau Jawa dapat dijabarkan sebagai berikut (Widyatmoko et al., 2010):

a. Aksara Palawa awal, dipakai sebelum abad $7 \mathrm{M}$, misalnya prasasti Tugu Bogor.

b. Aksara Palawa tahap akhir, dipakai pada abad $7 \mathrm{M}$ sampai pada pertengahan abad 8 $M$, misalnya prasasti di Canggal, Kedu dan Magelang.

c. Aksara Kawi atau Jawa Kuna tahap awal dipakai pada tahun 750 M - 725 M, misalnya prasasti Balengan di Kalasan, Yogyakarta.

d. Aksara Kawi atau Jawa Kuna tahap akhir dipakai pada tahun 925 M - 1250 M, misalnya prasasti Airlangga.

e. Aksara Majapahit dan aksara daerah/lokal dipakai pada tahun $1250 \mathrm{M}-1450 \mathrm{M}$, misalnya prasasti Singasari dan lontar "Kunjakarna".

f. Aksara Jawa Baru, dipakai pada tahun $1500 \mathrm{M}$ sampai sekarang, misalnya pada kitab "Sulah Bonang" dan kitab-kitab yang lebih muda.

Pada rentang tahun 1840-1940 mulai muncul aksara Jawa dalam bentuk metal type, untuk keperluan cetak (Molen, 1993). Usaha pembuatan metal type ini sebenarnya telah muncul sebelum tahun 1840, namun pembuatan desain bentuk aksara Jawa yang representatif baru selesai pada tahun 1840 . Metal type aksara Jawa yang berhasil dibuat tersebut banyak mengambil inspirasi dari bentuk aksara Jawa yang berasal dari Keraton Surakarta pada awal pertengahan abad ke-19. 
Berdasarkan Pedoman Penulisan Aksara Jawa yang dikeluarkan oleh KBJ (Kongres Basa Jawa) tahun 1996, carakan (aksara Jawa) yang digunakan di dalam ejaan bahasa Jawa pada dasarnya terdiri atas dua puluh aksara pokok (aksara Nglegena) yang bersifat silabik (kesukukataan). (Tim Penyusun Pedoman Penulisan Aksara Jawa, 1997). Masingmasing aksara pokok mempunyai aksara pasangan, yakni aksara yang berfungsi untuk menghubungkan suku kata tertutup konsonan dengan suku kata berikutnya.

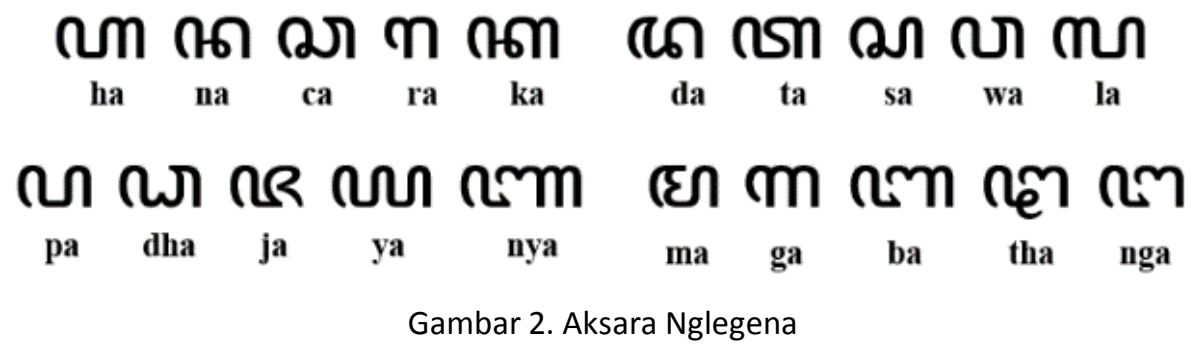

Selain aksara Nglegena, aksara Jawa juga dilengkapi dengan aksara Murda, aksara Suara, dan aksara Rekaan sebagai aksara pelengkap. Sebagai pengubah bunyi vokal, aksara Jawa perlu ditambahkan dengan sandangan. Sandangan dibedakan menjadi dua. Pertama, sandangan yang berfungsi sebagai pengubah bunyi vokal yang terdiri dari: wulu, pepet, suku, taling dan taling tarung. Kedua, sandangan yang berfungsi sebagai penutup suku kata yang terdiri dari: wignyan, layar, cecak, pangkon.

\subsection{Anatomi Aksara Jawa}

Dalam pengajaran tradisional, aksara Jawa ditulis dengan cara "menggantung" di bawah garis acuan. Jika mengacu pada teori tipografi, maka aksara Jawa ditulis "menggantung" pada meanline (garis batas atas). Hal ini dikarenakan aksara Jawa merupakan pengembangan dari aksara Kawi yang mengakar dari aksara Brahmi yang berasal dari daerah India bagian selatan. Karena merupakan turunan dari aksara Brahmi yang berasal dari India inilah yang menyebabkan penulisan aksara Jawa bersifat menggantung. Cara penulisan aksara Jawa menurut W van der Molen (1993), dalam bukunya "Javaans Schrift" ditulis dari arah kiri ke kanan seperti halnya dengan aksara sebelumnya ataupun aksara latin (Molen, 1993).

Setiap huruf pada dasarnya terbentuk dari elemen dasar berupa garis yang dapat dibaca menggunakan prinsip dasar anatomi huruf, maka hal ini diaplikasikan juga terhadap aksara Jawa. Analisa anatomi aksara Jawa dilakukan untuk mendeskripsikan elemenelemen aksara Jawa sesuai dengan terminologi yang relevan dengan konteks tipografi yang berlaku di Indonesia. Berikut penjelasan anatomi aksara Jawa berdasarkan ilmu tipografi yang mengacu pada Surianto Rustan (Rustan, 2014): 


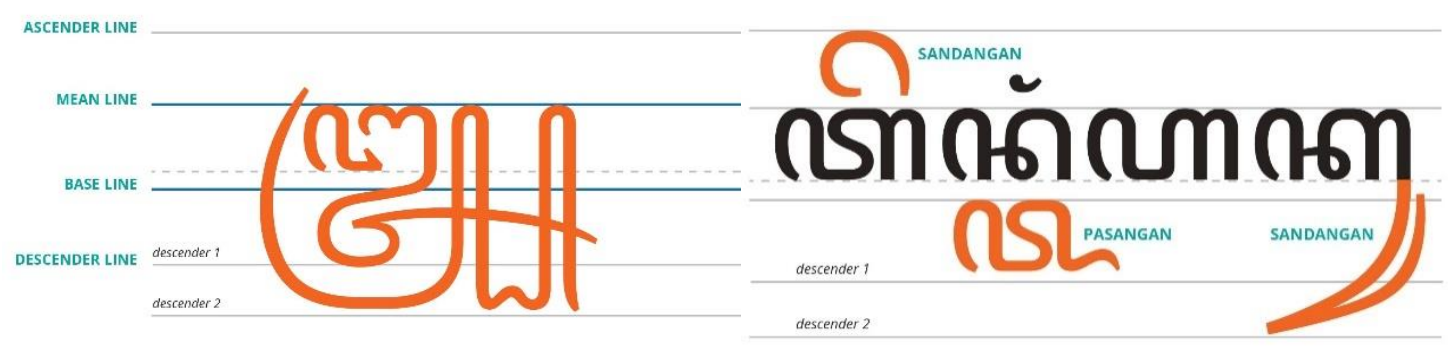

Gambar 3. Anatomi aksara Jawa

Tabel 1. Anatomi aksara Jawa

\begin{tabular}{|c|c|}
\hline Bagian Aksara & Nama dan Keterangan \\
\hline & $\begin{array}{l}\text { Bagian Awal } \\
\text { Tarikan garis lengkung yang mengawali hampir } \\
\text { di semua aksara Jawa. }\end{array}$ \\
\hline & $\begin{array}{l}\text { Bagian Akhir } \\
\text { Tarikan garis lengkung yang mengakhiri hampir } \\
\text { di semua aksara Jawa. }\end{array}$ \\
\hline & $\begin{array}{l}\text { Bagian Tengah } \\
\text { Berbeda dengan bagian awal dan akhir aksara } \\
\text { yang umumnya seragam, bagian tengah } \\
\text { biasanya memiliki bentuk khas tertentu yang } \\
\text { berperan penting sebagai pembeda antar } \\
\text { aksara. }\end{array}$ \\
\hline & $\begin{array}{l}\text { Lembah } \\
\text { Tarikan garis mendatar di bagian bawah aksara, } \\
\text { berbentuk seperti huruf 'u'. } \\
\text { Bagian lembah biasanya ditulis lebih lebar } \\
\text { daripada bagian bukit. }\end{array}$ \\
\hline & $\begin{array}{l}\text { Bukit } \\
\text { Tarikan garis lengkung di bagian atas aksara, } \\
\text { berbentuk seperti huruf ' } n \text { '. }\end{array}$ \\
\hline & $\begin{array}{l}\text { Akhiran Bukit } \\
\text { Bukit pada akhiran aksara dapat berbentuk } \\
\text { tumpul atau runcing. Dalam naskah cetak, bukit } \\
\text { semi-runcing biasanya digunakan apabila } \\
\text { terdapat dua bukit bersebelahan yang } \\
\text { dipisahkan oleh celah. }\end{array}$ \\
\hline & $\begin{array}{l}\text { Tanpa Celah vs Celah } \\
\text { Dua bukit yang bersebalahan dapat dipisahkan } \\
\text { dengan sebuah celah sempit. Celah bersifat } \\
\text { opsional dan penggunaannya bergantung pada } \\
\text { selera dan gaya penulisannya. }\end{array}$ \\
\hline
\end{tabular}




\begin{tabular}{|c|c|}
\hline Bagian Aksara & Nama dan Keterangan \\
\hline & $\begin{array}{l}\text { Kail } \\
\text { Tarikan terminal yang berada di bagian tengah } \\
\text { aksara. Kail ditulis secara menyambung antara } \\
\text { bagian bawah dan bagian atas dikarenakan } \\
\text { pena tidak diangkat dalam penulisan satu } \\
\text { aksara tersebut. }\end{array}$ \\
\hline & $\begin{array}{l}\text { Gerigi Atas } \\
\text { Tarikan menukik ke bawah pada bagian bukit. }\end{array}$ \\
\hline & $\begin{array}{l}\text { Gerigi Bawah } \\
\text { Tarikan menukik ke atas pada bagian lembah. }\end{array}$ \\
\hline Simpul kiri - kanan & $\begin{array}{l}\text { Simpul } \\
\text { Tarikan garis yang berbentuk lingkaran. Simpul } \\
\text { umumnya berukuran kecil. Pada beberapa } \\
\text { naskah, simpul tidak memiliki counter dan dapat } \\
\text { memiliki swash yang besar. }\end{array}$ \\
\hline & $\begin{array}{l}\text { Cross Stroke } \\
\text { Tarikan garis yang melintang/memotong garis } \\
\text { lain. Terdapat dua variasi garis yaitu yang } \\
\text { berbentuk pendek dan panjang. }\end{array}$ \\
\hline & $\begin{array}{l}\text { Cerek } \\
\text { Garis lengkung yang digunakan pada beberapa } \\
\text { huruf untuk memunculkan bunyi khusus. }\end{array}$ \\
\hline Aksara unik & $\begin{array}{l}\text { Bentuk Unik } \\
\text { Beberapa aksara Jawa memiliki komponen yang } \\
\text { sepenuhnya unik dan tidak dimiliki oleh aksara } \\
\text { yang lainnya. }\end{array}$ \\
\hline Komponen unikRibs & Eye \\
\hline
\end{tabular}




\begin{tabular}{|l|l|}
\hline Bagian Aksara & \multicolumn{1}{|c|}{ Nama dan Keterangan } \\
\hline & $\begin{array}{l}\text { Sudut Tulis } \\
\text { Aksara Jawa tidak mengenal sistem penulisan } \\
\text { bergaya miring (italic). Maka dari itu penulisan } \\
\text { naskah Jawa bisa sepenuhnya tegak maupun } \\
\text { miring ke kanan, sesuai dengan gaya } \\
\text { penulisannya. Namun secara umum, penulisan } \\
\text { aksara Jawa menggantung pada garis acuan atas } \\
\text { dan miring ke kanan. }\end{array}$ \\
\hline
\end{tabular}

\subsection{Aksara Jawa di Era Digital}

Unicode Standard adalah standar dalam dunia komputer untuk pengkodean (encoding) karakter tertulis dan teks yang mencakup hampir semua sistem penulisan yang ada di dunia. Dengan adanya Unicode, pertukaran data teks dapat terjadi secara universal dan konsisten. Unicode adalah encoding defaultpada HTML dan XML, dan diimplementasikan di semua sistem operasi modern seperti Windows dan Mac OS. Unicode menjadi dasar untuk standar-standar modern dan bahasa komputer seperti Java, C\#, Microsoft .NET Framework, ECMAScript (JavaScript), WML, dan lainnya.

Aksara Jawa sudah resmi masuk dalam Unicode versi 5.2 sejak 2009. Dengan masuknya aksara Jawa dalam Unicode, maka membuat aksara Jawa bisa dengan leluasa digunakan pada perangkat-perangkat digital, seperti PC, Netbook, Tablet, dan bentuk gadget lainnya. Hal ini merupakan sebuah kesempatan yang dapat dimanfaatkan untuk lebih mengenalkan kembali aksara Jawa secara lebih luas.

Dengan masuknya aksara Jawa dalam Unicode, juga membuka pintu bagi para fontdesigner untuk menciptakan aksara Jawa yang bisa digunakan untuk keperluan digital. Berikut beberapa contoh font aksara Jawa yang telah ada dan bisa diunduh secara gratis maupun berbayar.

Tabel 2. Contoh font aksara Jawa

\begin{tabular}{|c|c|c|}
\hline Bentuk Font & Nama Font & Font Designer \\
\hline 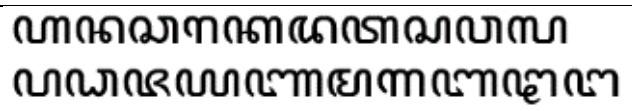 & Pustaka Jawa & Aditya Bayu \\
\hline 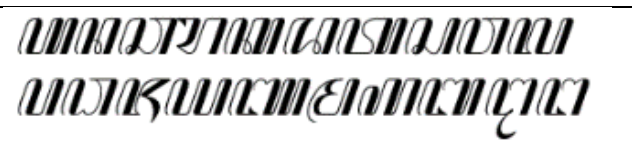 & Makara & Aditya Bayu \\
\hline 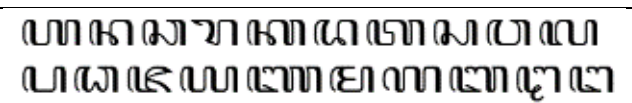 & Tuladha Jejeg & R.S. Wihananto \\
\hline
\end{tabular}




\subsection{Website Informasi Aksara Jawa}

Ide dalam perancangan ini adalah mengemas informasi tentang aksara Jawa ke dalam media yang baru. Analisa tentang aksara Jawa yang diuraikan pada bab sebelumnya digunakan sebagai rujukan dalam perancangan desain informasi aksara Jawa menggunakan media digital website. Informasi yang ditampilkan berupa sejarah tentang perkembangan bentuk aksara Jawa mulai dari aksara Pallawa, aksara Kawi (Jawa Kuno) hingga bentuk aksara Jawa baru (modern), cara penulisan aksara Jawa disertai dengan contoh penggunaannya dalam sebuah kata, serta makna-makna filosofis yang terkandung dalam aksara Jawa. Untuk menunjang pengguna mempelajari cara menulis aksara Jawa, dalam media digital ini juga ditampilkan tutorial cara menulis aksara Jawa dalam bentuk video dan juga lembar garis bantu untuk menulis aksara Jawa yang dapat diunduh oleh pengguna. Semua unsur-unsur tersebut akan dirancang sedemikian rupa sesuai dengan selera masyarakat kini dan hasil survei yang dilakukan sebelumnya, sesuai dengan tujuan perancangan yang ingin melestarikan serta mengenalkan kembali aksara Jawa kepada masyarakat awam, khususnya generasi muda.

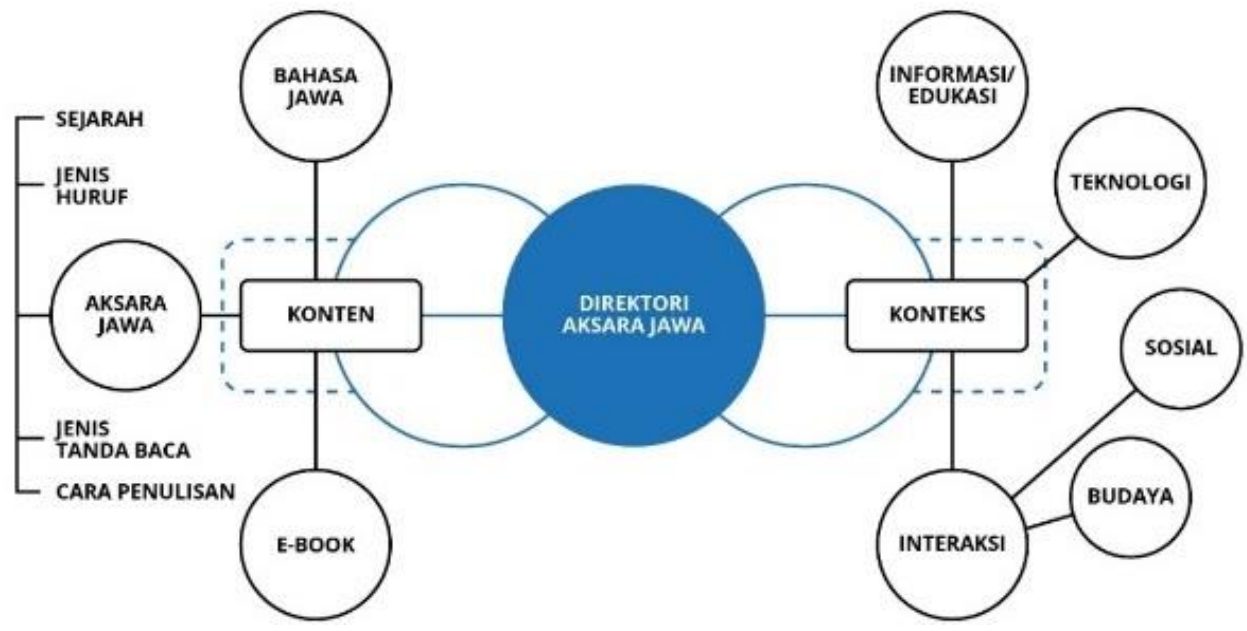

Gambar 4. Konsep umum website Hanacara

[Sumber: Dokumentasi Penulis]

Format direktori dipilih untuk menyajikan semua unsur informasi tersebut dalam susunan yang rapi dan sistematis, serta disajikan dalam bentuk tulisan, gambar dan animasi (Pettersson, 2002), sehingga pengguna akan dengan mudah mempelajari konten aksara Jawa yang terdapat di dalam website. Untuk konten yang berisi tentang sejarah aksara Jawa, akan ditampilkan deskripsi berupa sejarah perubahan bentuk aksara beserta contoh prasasti maupun manuskrip yang bersangkutan. Sedangkan konten inti dari website ini adalah materi aksara Jawa yang berisi tentang jenis-jenis aksara Jawa yang nantinya pengguna dapat masuk dalam penjelasan masing-masing aksara Jawa secara lebih terperinci, mulai dari cara penulisan aksara Jawa, contoh kata dalam bentuk animasi, serta makna filosofis yang terkandung dalam setiap aksara Jawa.

Penggunaan website sebagai media utama dalam menyampaikan informasi tentang aksara Jawa juga didukung dengan media sosial lainnya yang saling terhubung agar lebih banyak khalayak yang mengetahui keberadaannya. Dalam hal ini, penggunaan media 
sosial seperti Facebook, Twitter, dan YouTube digunakan sebagai media pendukung website informasi aksara Jawa ini.

Perancangan website ini dibagi dalam tiga konten besar, yaitu sejarah aksara Jawa, jenis aksara Jawa dan transliterasi aksara Jawa. Untuk konten yang berisi tentang sejarah aksara Jawa, akan ditampilkan deskripsi berupa sejarah perubahan bentuk aksara beserta contoh prasasti maupun manuskrip yang bersangkutan. Sedangkan konten inti dari website ini adalah materi aksara Jawa yang berisi tentang jenis-jenis aksara Jawa yang nantinya pengguna dapat masuk dalam penjelasan masing-masing aksara Jawa secara lebih terperinci, mulai dari cara penulisan aksara Jawa, contoh kata dalam bentuk animasi, serta makna filosofis yang terkandung dalam setiap aksara Jawa. Sebagai upaya aktualisasi aksara Jawa secara lebih kekinian, pada website informasi ini juga dilengkapi dengan fitur transliterasi aksara Jawa. Pengguna bisa menuliskan kata maupun kalimat dalam huruf latin kemudian akan secara otomatis diterjemahkan dalam bentuk tulisan aksara Jawa, begitu pula sebaliknya.

\subsection{Konsep Visual}

Konsep visual yang dirancang berdasarkan analisa aksara Jawa yang diikuti oleh desain grafis dalam aplikasi yang mengikutinya. Perupaan dalam perancangan merujuk pada gaya visual manuskrip aksara Jawa, seperti ornamen-ornamen pada wedana, rerenggan, pola ragam hias Jawa, serta unsur visual maupun tipografi pada bentuk aksara Jawa. Selain mengambil rujukan dari gaya visual manuskrip aksara Jawa, dirujuk pula referensi gaya visual yang sedang populer di masa kini. Sehingga perancangan ini memiliki posisi di tengah-tengah gaya visual tradisi aksara Jawa dan gaya visual masa kini.

\subsubsection{Warna}

Konsep warna yang dipakai pada perancangan website ini diambil dari warna-warna iluminasi (wedana dan rerenggan) manuskrip aksara Jawa yang cenderung berwarna jingga keemasan, sebagai warna primer. Iluminasi yang yang diacu salah satunya adalah yang terdapat pada manuskrip Serat Jayalengkara (1803). Selain iluminasi, lambang Keraton Ngayogyakarta, Kadipaten Pakualaman, dan Keraton Surakarta juga dijadikan referensi dalam pemilihan konsep warna yang digunakan pada website. Lambanglambang Keraton ini dipilih menjadi referensi karena kebudayaan Jawa banyak berpusat pada kehidupan Keraton dan banyak manuskrip-manuskrip aksara Jawa yang dikeluarkan oleh Keraton. 


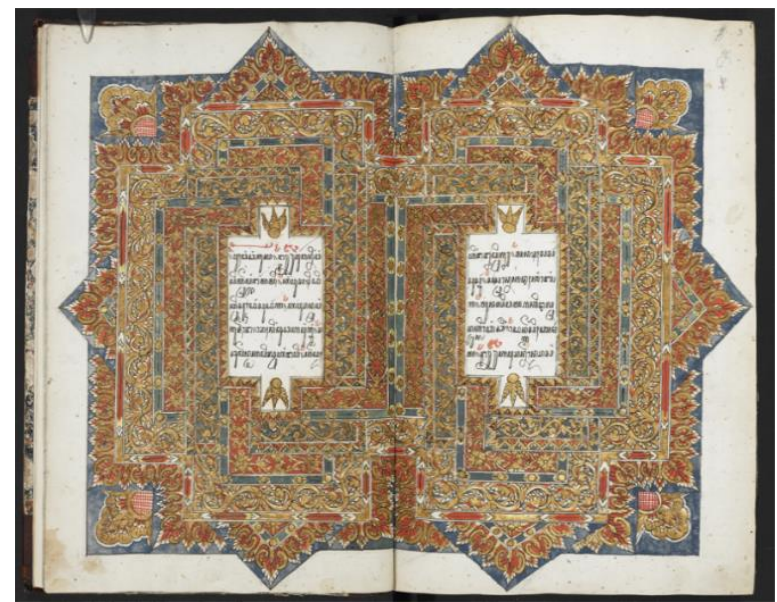

Gambar 5. Wedana pada serat Jayalengkara

[Sumber: Naskah-Naskah Skriptorium Pakualaman (2016)]

Kemudian warna primer yang terpilih diolah dengan sistem warna triadik sehingga didapatkan warna-warna lain sebagai warna sekunder. Penggunaan sistem warna triadik bertujuan untuk untuk menimbulkan kesan ceria, aktif, dan kesucian (Yogananti, 2015). Warna hijau dan biru yang didapatkan dari sistem warna triadik juga sesuai dengan lambang Keraton Surakarta dan Kadipaten Pakualaman yang dijadikan sebagai referensi. Warna biru dalam lambang Keraton Surakarta merupakan simbol angkasa atau langit, merupakan simbol orang yang berwatak luas pandangannya dan juga pemberi maaf. Sedangkan warna hijau dalam lambang Kadipaten Pakualaman memiliki makna membangkitkan energi dan juga mampu memberi efek menenangkan, menyejukkan, dan menyeimbangkan emosi.
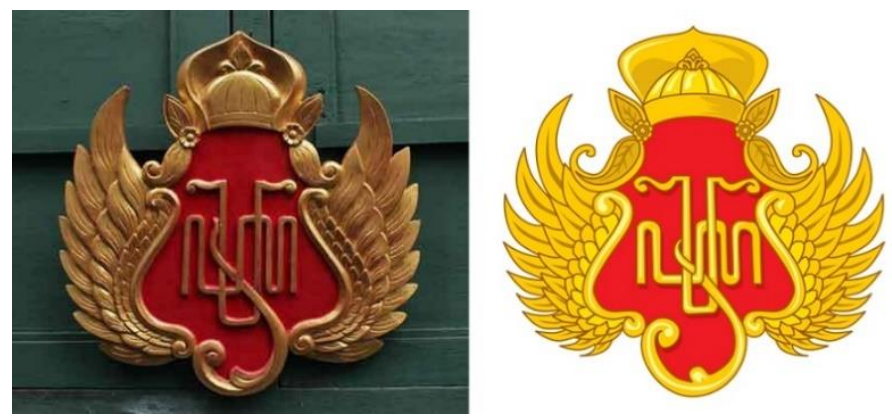

Gambar 6. Lambang Keraton Ngayogyakarta [Sumber: http://keraton.perpusnas.go.id/node/71]
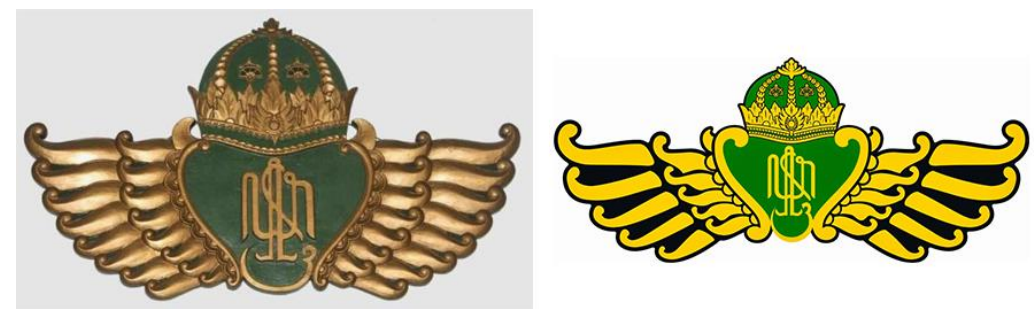

Gambar 7. Lambang Kadipaten Pakualaman

[Sumber: http://erizalbarnawi.blogspot.co.id/2014/04/simbol-dan-makna-kadipaten-pakualaman.html] 


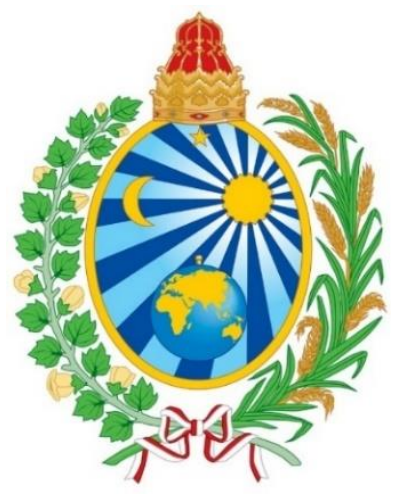

Gambar 8. Lambang Keraton Surakarta

[Sumber: http://keraton.perpusnas.go.id/node/76]

Penggunaan warna-warna ini bertujuan untuk memunculkan kesan masa kini sesuai dengan target perancangan yaitu remaja SMA, namun dengan tetap mempertahankan kesan klasik (Jawa) melalui tambahan ornamen-ornamen di beberapa bagian halaman website. Secara tidak langsung, dengan pemilihan warna-warna ini diharapkan para pengguna nantinya memahami bahwa warna-warna tersebut sebenarnya merupakan representasi dari budaya mereka sendiri, yaitu budaya Jawa yang diwakilkan oleh Keraton.

\subsubsection{Ilustrasi}

Gaya ilustrasi yang digunakan di halaman header dan beberapa halaman lain seperti yang digunakan pada contoh kata, merujuk pada gaya ilustrasi yang sedang popular di masa kini, yaitu gaya ilustrasi digital flat design. Gaya ini dipilih karena bentuknya yang menarik dan menunjukkan bentuk deformasi atau penyederhanaan, seperti yang banyak digunakan dalam film animasi serta tampilan website maupun media sosial masa kini. Pemilihan gaya ilustrasi digital flat design ini dipilih juga karena penyajiannya yang ringan untuk masyarakat umum yang tidak semua peka dengan ilmu desain dan ilustrasi.

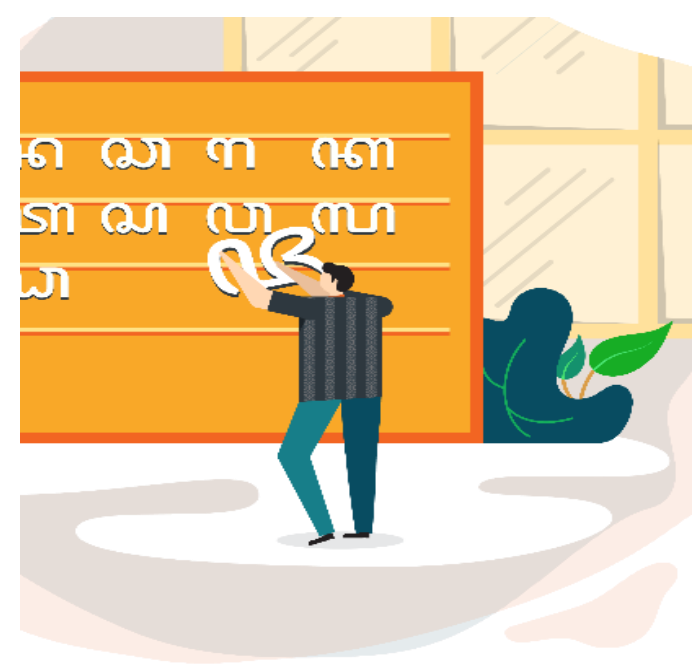

Gambar 9. Ilustrasi pada halaman website

[Sumber: Dokumentasi penulis] 
Gaya flat design juga sesuai dengan target perancangan yaitu siswa SMA, yang cenderung lebih menyukai bentuk visual yang lebih modern dan kekinian. Sehingga diharapkan informasi dapat disampaikan secara visual dengan lebih ringan, lebih umum, dan lebih bisa diterima masyarakat umum namun dengan tetap mempertahankan karakteristik visual Jawa.

\subsubsection{Halaman Website dan Sistem Navigasi}

Sistem navigasi yang digunakan adalah sistem click and go, maksudnya dari sistem ini adalah cara penggunaannya dengan memberi input pilihan yang kemudian akan diproses menuju perintah atau halaman selanjutnya yang ingin dituju. Untuk layout disesuaikan dengan format desktop yang berorientasi horizontal, seperti bentuk website secara umum.

Pada halaman 'Index' (utama) berisi tentang ringkasan topik utama yang ingin disampaikan pada website informasi aksara Jawa. Pada halaman ini terdapat navigasi untuk memilih halaman selanjutnya yang akan dituju. Halaman tersebut antara lain halaman Sejarah, Aksara, Infografis, Transliterasi, dan Informasi. Video tutorial cara menulis aksara Jawa juga ditampilkan pada halaman 'index' ini beserta dengan lembaran garis bantu yang bisa diunduh oleh pengguna.
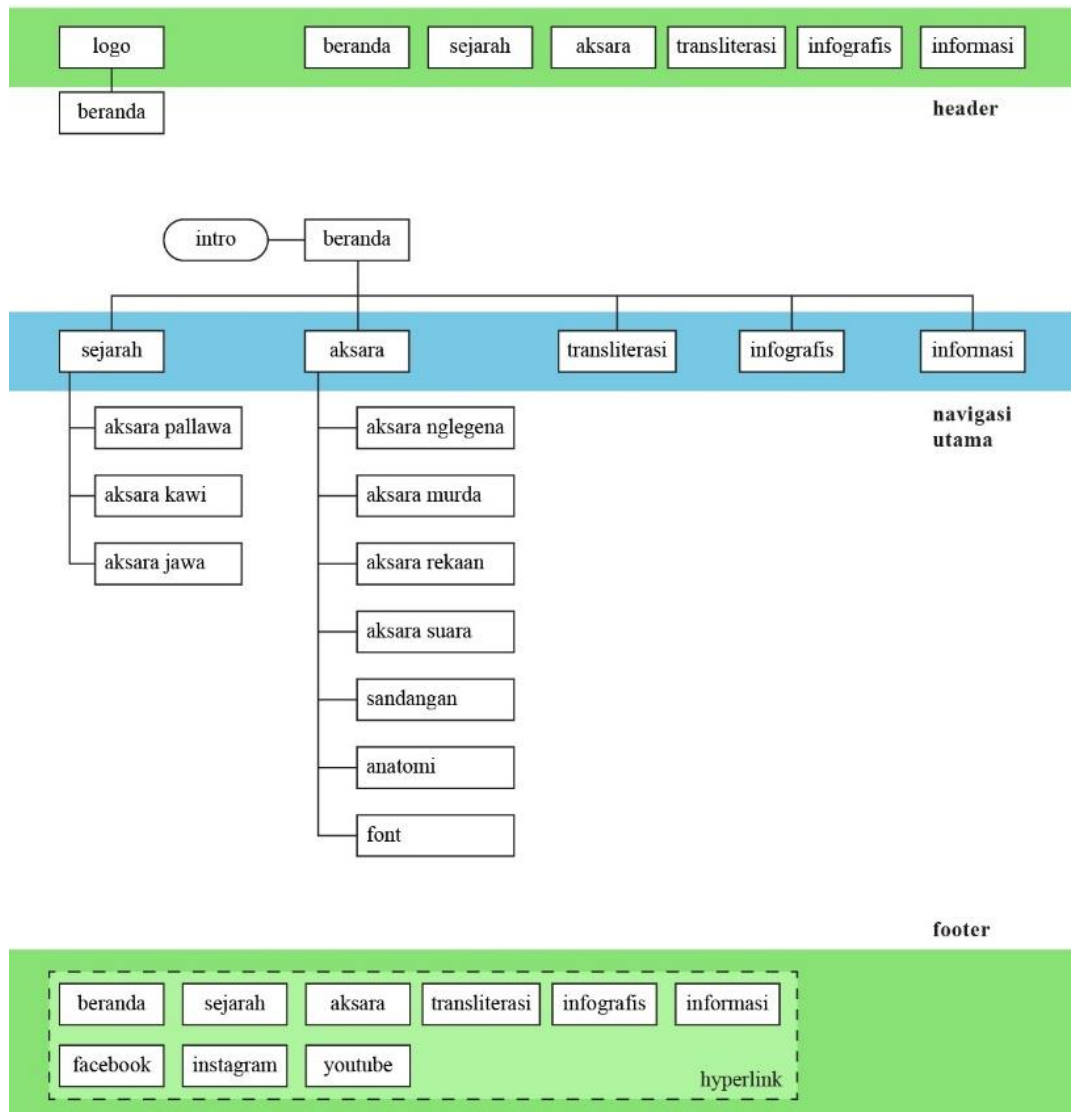

Gambar 10. Hirarki website informasi aksara Jawa

[Sumber: Dokumentasi penulis] 

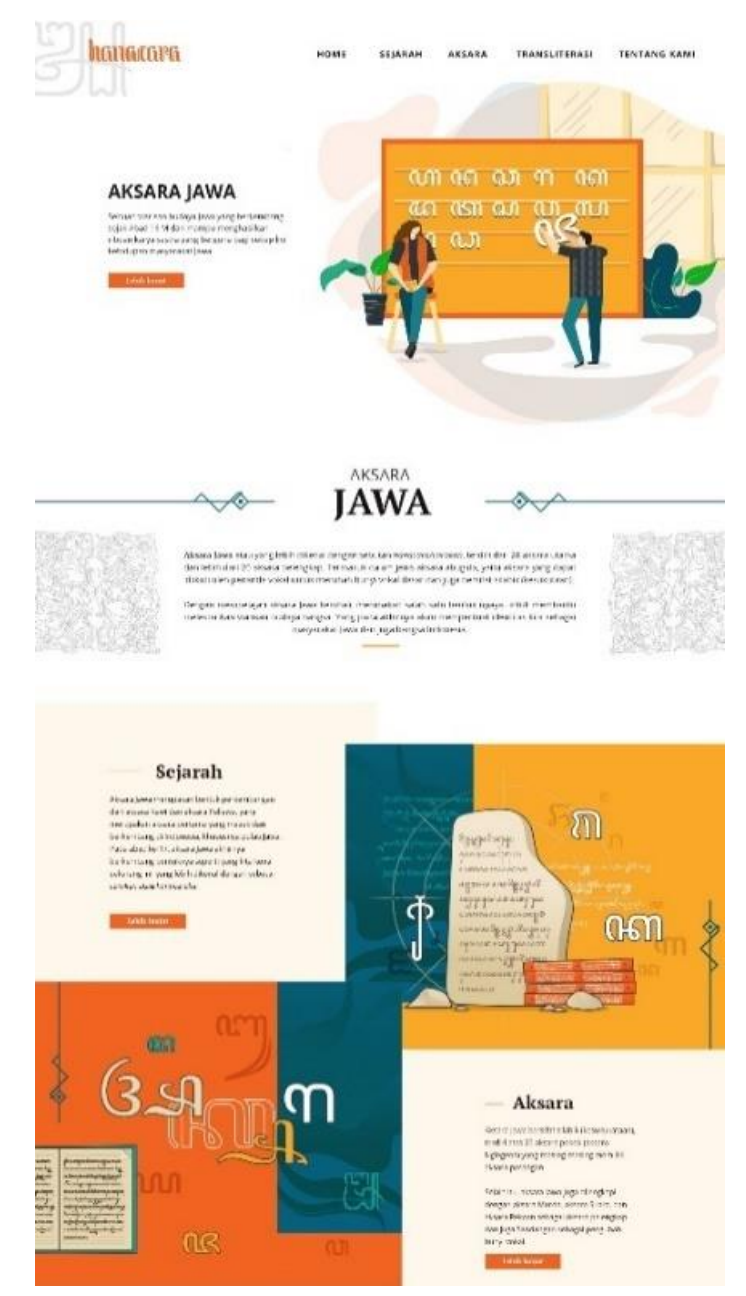

Gambar 11. Contoh potongan halaman 'Index' [Sumber: Dokumentasi penulis]

Selanjutnya di dalam halaman 'Sejarah' akan ditampilkan informasi berupa deskripsi perkembangan bentuk aksara Jawa berupa teks dan juga dilengkapi dengan gambar maupun foto terkait. Informasi yang ditampilkan dibagi menjadi tiga halaman, yaitu halaman aksara Pallawa, aksara Kawi, dan aksara Jawa.

Halaman 'Aksara' menjadi pokok utama dalam website ini. Halaman ini memiliki beberapa sub-menu lagi yang bisa dipilih diantaranya, aksara Nglegena, aksara Murda, aksara Swara, aksara Rekaan, Sandangan, anatomi aksara Jawa dan font aksara Jawa. Dalam setiap sub-menu tersebut berisi informasi detail tentang jenis-jenis aksara yang bersangkutan mulai dari cara penulisannya, aksara pasangannya, dan contoh kata dalam bentuk teks maupun animasi motion graphic. 


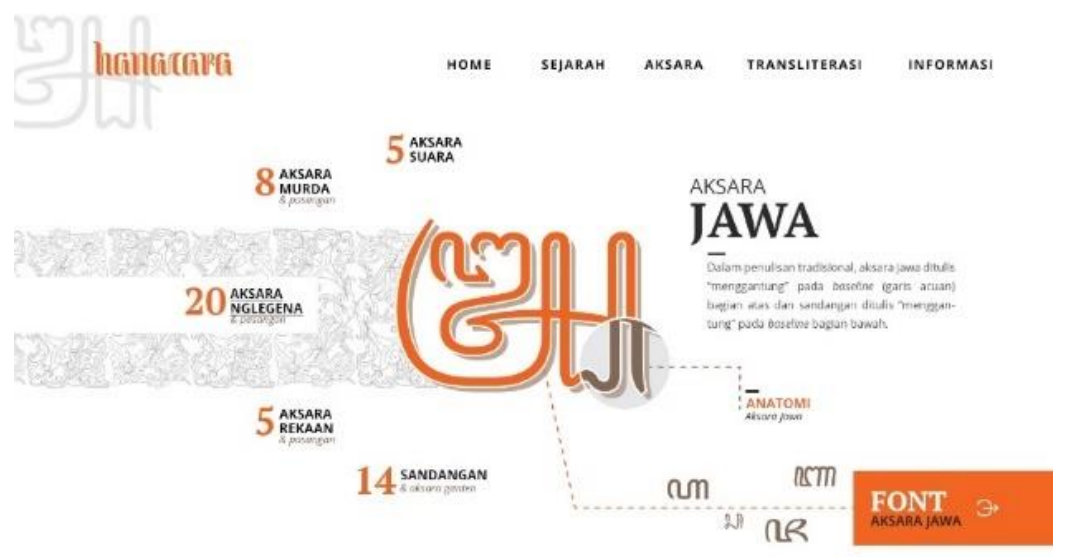

Gambar 12. Halaman Pilihan Aksara

[Sumber: Dokumentasi penulis]

Untuk halaman anatomi berisi tentang informasi anatomi aksara Jawa secara ilmu tipografi. Sedangkan halaman font aksara Jawa berisi tentang beberapa macam jenis font aksara Jawa yang telah ada dan dapat diunduh oleh pengguna serta informasi tentang standar Unicode yang dipakai sebagai standar pembuatan font aksara Jawa. Untuk meningkatkan ketertarikan pengguna terhadap aksara Jawa, dalam website ini terdapat halaman infografis dan transliterasi. Pada halaman infografis, akan ditampilkan berbagai macam bentuk infografis tentang berbagai macam budaya yang ada di masyarakat Jawa menggunakan aksara Jawa. Sedangkan pada halaman transliterasi, pengguna dapat menulis kata dalam huruf latin yang kemudian akan diterjemahkan dalam bentuk tulisan aksara Jawa maupun sebaliknya.
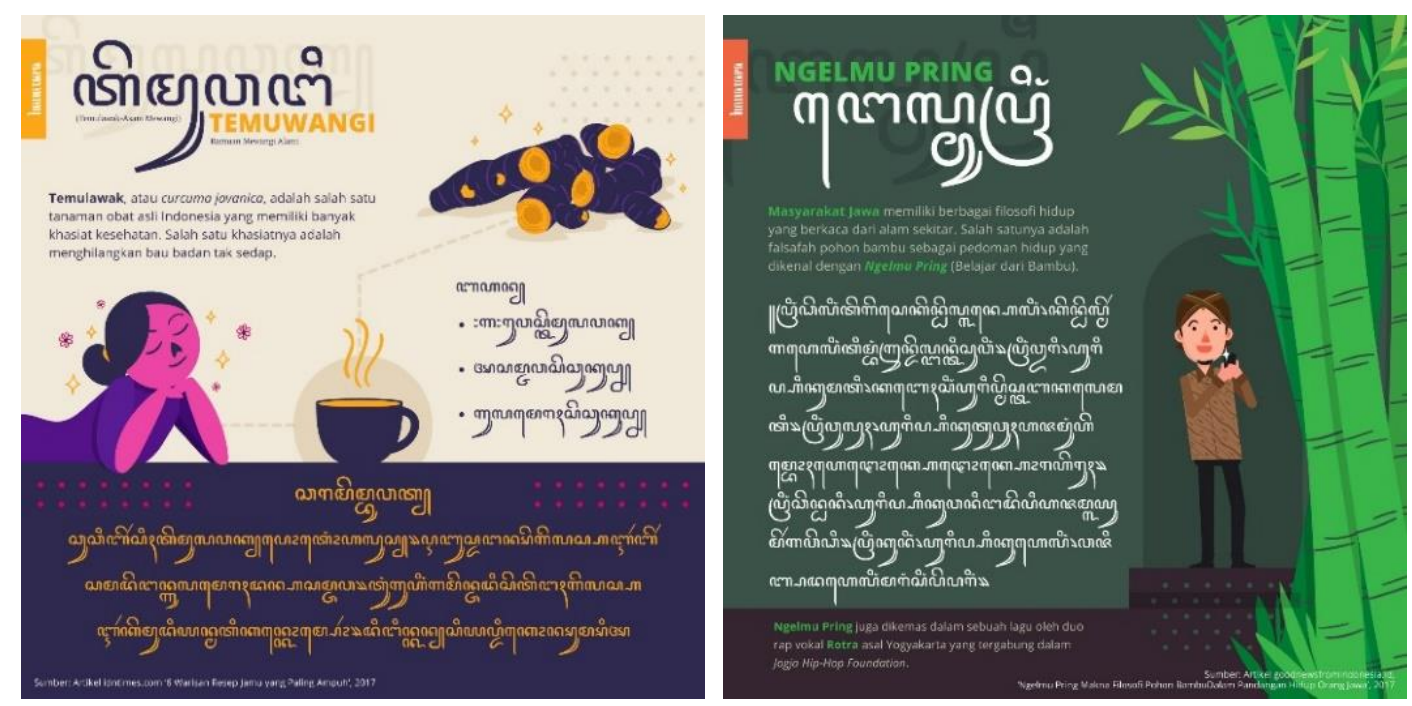

Gambar 13. Contoh gambar pada halaman Infografis [Sumber: Dokumentasi penulis] 


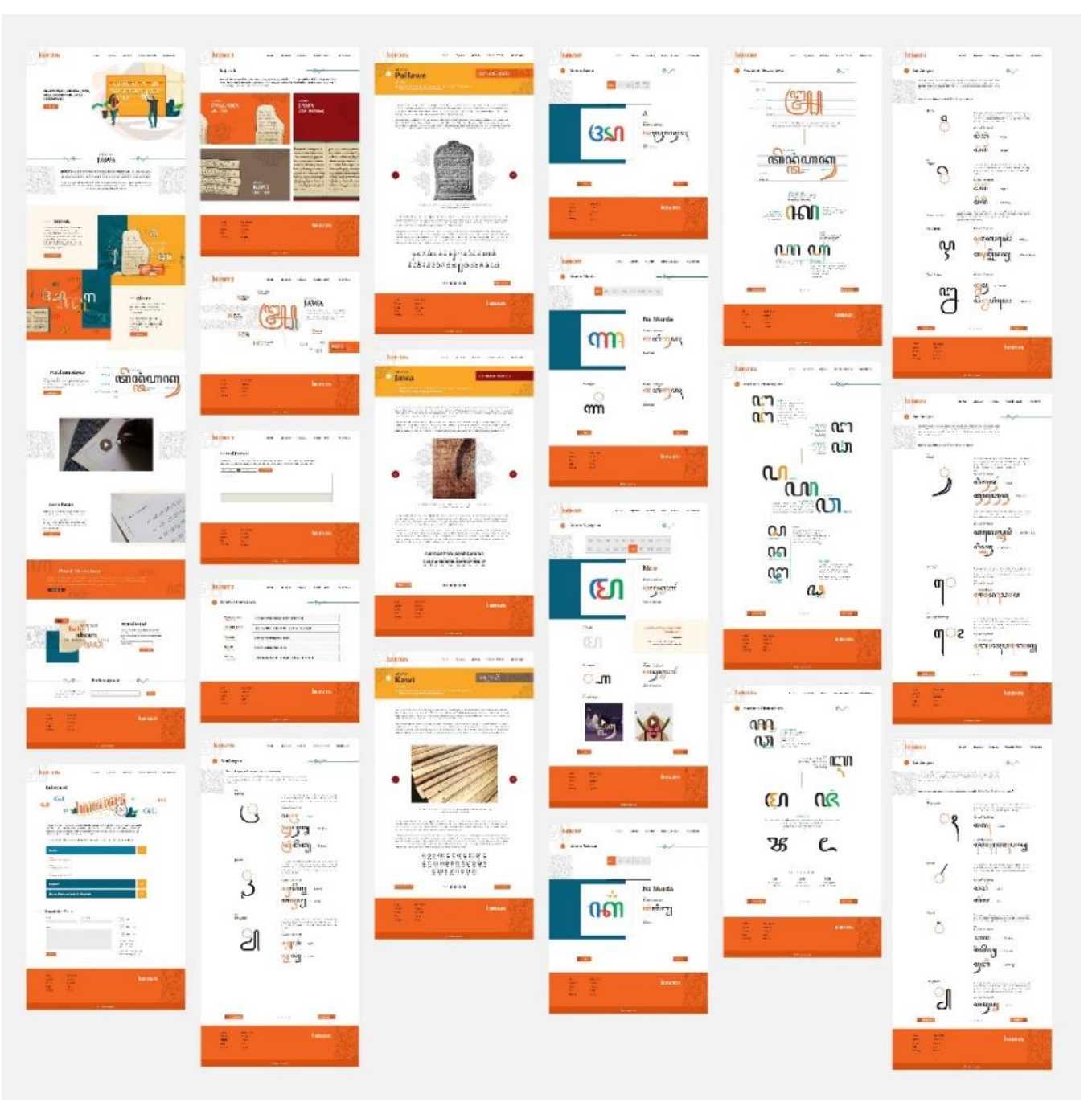

Gambar 14. Keseluruhan halaman website

[Sumber: Dokumentasi penulis]

\subsubsection{Logo dan Tipografi}

Konsep logo diambil dari bentuk aksara Jawa yang dimodifikasi menjadi bentuk alfabetis. Pemilihan nama 'Hanacara' sebagai nama website diambil dari nama aksara Jawa yang biasa disebut hanacaraka. Selain itu, Hanacara jika dibagi menjadi dua kata 'hana' dan 'cara' merupakan bahasa Jawa yang memiliki arti 'ada cara'. Pemilihan nama ini mewakili maksud dan tujuan dari pembuatan website aksara Jawa, yaitu sebagai salah satu cara untuk menyampaikan informasi dan petunjuk untuk lebih mengenalkan kembali aksara Jawa kepada masyarakat umum.

\section{lngillGilciler}

Gambar 15. Logo hanacara 
Untuk isi konten website menggunakan tiga jenis fontset/kelompok huruf untuk memenuhi kebutuhan grafis aplikasi.

1. Pustaka Jawa YCG, oleh Aditya Bayu. Digunakan untuk penulisan aksara Jawa yang ada di dalam website.

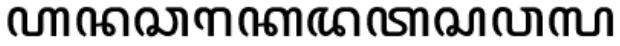

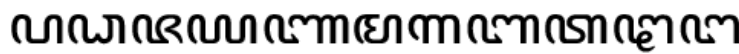

Gambar 16. Font Pustaka Jawa YCG

2. PT Serif, oleh ParaType. Digunakan untuk penulisan menu utama, headline artikel yang ada di dalam website. Pemilihan jenis font serif ini untuk memunculkan nuansa klasik serta elegan.

\section{ABCDEFGHIJKLMNOPQRSTUVWXYZ abcdefghijklmnopqrstuvwxyz}

Gambar 17. Font PT Serif

3. Open Sans, oleh Ascender Fonts. Jenis font sans serif ini digunakan untuk penulisan header menu, konten artikel dan keterangan lainnya. Pemilihan jenis font ini untuk memunculkan kesan simple, dinamis dan modern.

\section{ABCDEFGHIJKLMNOPQRTUVWXYZ abcdefghijklmnopqrtuvwxyz}

\author{
Gambar 18. Font YCG Open Sans
}

\subsection{Konsep Media}

Media yang akan digunakan pada perancangan ini adalah sebuah website yang bisa diakses pengguna melalui browser, baik secara desktop (PC/komputer), tablet, maupun smartphone. Alasan pemilihan media ini adalah kemudahan bagi para pengguna untuk mengaksesnya di mana saja dan kapan saja melalui browser yang telah banyak tersedia pada media desktop, tablet, maupun smartphone.

Penggunaan website sebagai media utama dalam menyampaikan informasi tentang aksara Jawa perlu didukung dengan media internet lainnya yang saling terhubung agar lebih banyak khalayak yang mengetahui keberadaannya. Dalam hal ini, penggunaan media sosial seperti Facebook, Twitter, dan YouTube digunakan sebagai media pendukung website informasi aksara Jawa ini. 


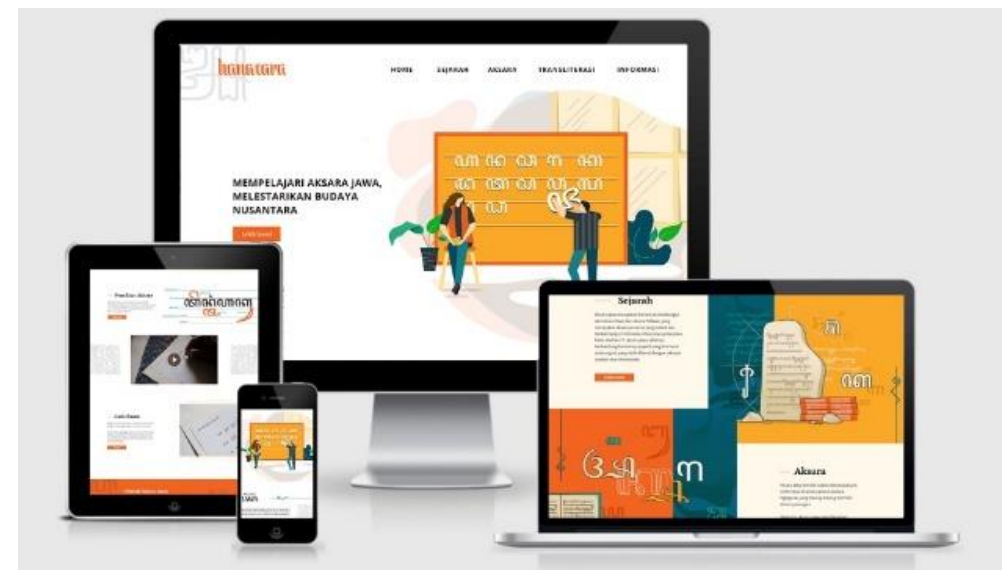

Gambar 19. Tampilan website Hanacara dalam berbagai media [Sumber: Dokumentasi penulis]

Beberapa media sosial yang digunakan sebagai media pendukung diantaranya, fan page Facebook yang dapat digunakan untuk memberikan informasi berupa artikel, diskusi, maupun menayangkan video dengan berbagai durasi yang berkaitan dengan aksara Jawa. Halaman fan page Facebook bisa diakses melalui https://www.facebook.com/hanacara.id.

Selanjutnya, YouTube digunakan sebagai media untuk membagikan video berupa tutorial menulis aksara Jawa maupun video lainnya yang berkaitan dengan aksara Jawa. Pemilihan YouTube sebagai platform untuk membagikan video berdasar pada survei yang dilakukan oleh Nielsen (2017) yang menunjukkan bahwa YouTube menempati posisi pertama di Indonesia sebagai media yang paling sering diakses untuk melihat video secara online. Halaman channel Youtube bisa diakses dengan username 'Hanacara Aksara', atau melalui tautan https://www.youtube.com/channel/ UCeEQwtQhFt7ilxcEKKvCiUw/.

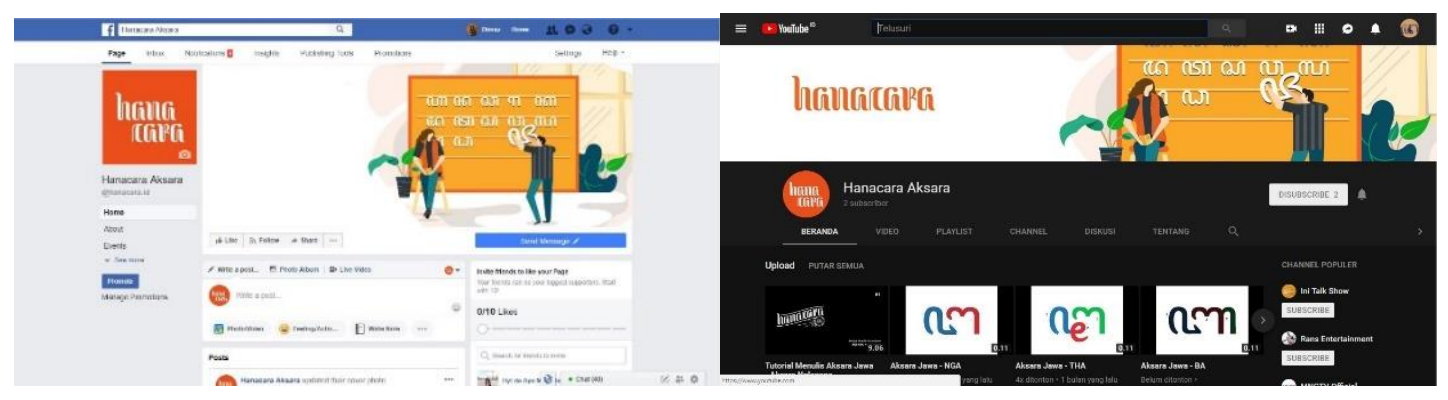

Gambar 20. Fan page Facebook dan halaman Youtube Hanacara [Sumber: Dokumentasi penulis]

Kemudian Instagram juga digunakan sebagai media pendukung untuk membagikan konten tentang askara Jawa baik berupa gambar, video animasi, maupun video tutorial singkat. Penggunaan Instagram dan Facebook sebagai media terpilih berdasar pada survei yang dilakukan oleh JAKPAT (2017) yang menunjukkan bahwa Facebook dan Instagram menduduki posisi 1 dan 2 sebagai platform media sosial yang paling sering digunakan untuk mendapatkan informasi. Halaman Instagram Hanacara bisa diakses 
dengan mencari username 'hanacara.id', atau melalui tautan https://www.instagram.com/hanacara.id/.

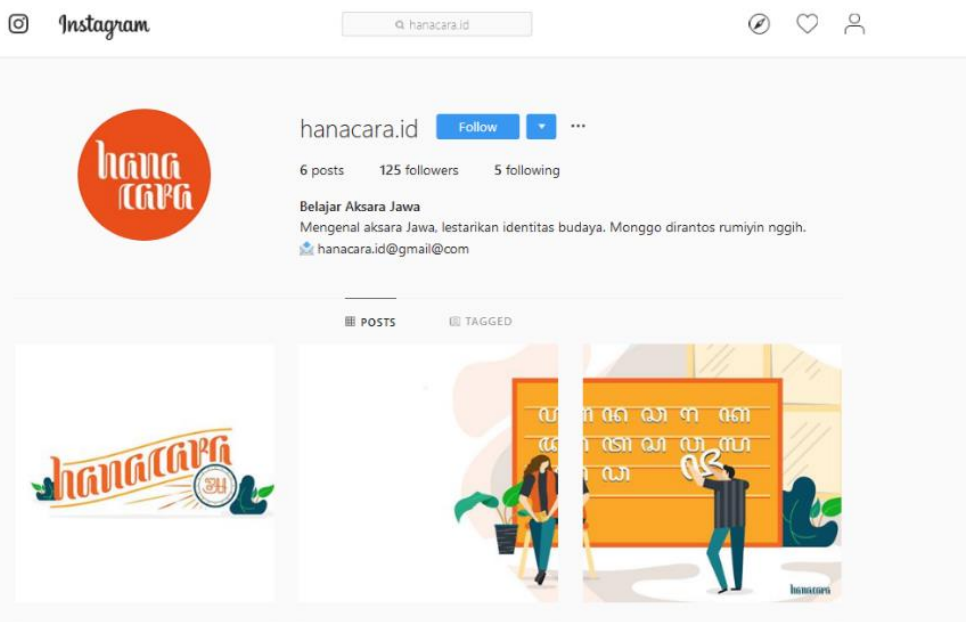

Gambar 21. Halaman Instagram Hanacara

[Sumber: Dokumentasi penulis]

\subsection{Hasil Uji Coba}

Untuk mendapatkan respon terhadap hasil perancangan website Hanacara, dilakukan uji coba website pada sejumlah responden sesuai dengan sasaran pengguna dalam perancangan ini yaitu remaja SMA. Pengambilan responden dilakukan dengan menggunakan teknik purposive sampling. Uji coba dilakukan dengan cara responden mencoba mengoperasikan website Hanacara kemudian mengisi kuesioner yang telah disiapkan. Ada empat aspek respon yang akan ditanyakan dalam kuesioner website Hanacara yaitu, aspek visual, aspek komunikatif, aspek pembelajaran, dan aspek apresiasi.

Berdasarkan hasil uji coba yang telah dilakukan, hasil jawaban responden pada aspek visual dinilai masuk dalam kategori "Baik" atau "Menarik" karena rata-rata presentase nilai dari masing-masing pernyataan aspek visual mendapatkan nilai sebesar $79,44 \%$. Hampir keseluruhan responden merasa puas dengan tampilan visual website Hanacara yang menampilkan ciri khas visual Jawa dengan gaya masa kini dan dalam bentuk yang menarik. Selanjutnya, pada aspek komunikatif, responden menilai website Hanacara masuk dalam kategori "Baik" dengan rata-rata presentase nilai dari masing-masing pernyataan sebesar $76,38 \%$. Artinya, masih perlu ada evaluasi dan pengembangan lebih lanjut untuk memperbaiki aspek komunikatif pada website Hanacara.

Selanjutnya, pada aspek pembelajaran mendapatkan nilai persentase tertinggi menurut responden dengan nilai rata-rata dari masing-masing pernyataan sebesar $80,92 \%$ dan masuk dalam kategori "Baik". Secara keseluruhan, responden dapat mengerti dan memahami informasi-informasi yang ditampilkan pada website Hanacara. Dengan variasi format media yang digunakan untuk menyampaikan konten informasi merupakan nilai tambah yang menurut responden dapat memunculkan ketertarikan untuk mempelajari aksara Jawa lebih lanjut. Sedangkan pada aspek apresiasi, responden 
merasa terbantu dengan fitur-fitur yang tersedia dalam website Hanacara. Dengan nilai rata-rata dari masing-masing pernyataan sebesar $76,66 \%$, aspek apresiasi dalam website Hanacara masuk ke dalam kategori "Baik".

Secara keseluruhan, website Hanacara dapat berjalan dengan baik dan bisa dioperasikan oleh pengguna. Berdasarkan hasil uji coba dan hasil jawaban kuesioner, dapat diambil sebuah kesimpulan berdasarkan nilai rata-rata dari keempat aspek yang telah ditanyakan. Total persentase yang didapatkan sebesar 78,35\%, yang membuat website Hanacara secara keseluruhan masuk ke dalam kategori "Baik".

\section{KESIMPULAN}

Aksara Jawa sebagai salah satu warisan budaya bangsa yang merupakan ciri khas dari budaya Jawa dan juga menjadi bagian dari identitas masyarakat Jawa. Upaya pelestarian aksara Jawa telah diupayakan oleh Pemerintah Daerah melalui penetapan mata pelajaran muatan lokal Bahasa Daerah pada jenjang pendidikan SD-SMP-SMA. Namun kenyataan di lapangan pembelajaran aksara Jawa dirasa masih belum maksimal karena keterbatasan jam pelajaran yang ada. Diperlukan sebuah upaya lebih lanjut dalam melestarikan aksara Jawa dan mengenalkannya kepada generasi muda, khususnya remaja. Namun untuk dapat masuk dalam ranah selera remaja masa kini, perlu dilakukan penyesuaian dari segi desain visual dan media penyampaian informasi aksara Jawa. Desain visual informasi aksara Jawa ini harus berdasarkan kajian sejarah aksara Jawa serta sistem tipografinya sehingga ciri khas budaya Jawa masih tetap muncul dalam perancangan desain visual baru.

Media yang efektif dalam penyampaian informasi tentang aksara Jawa adalah melalui media website. Dengan menggabungkan kemampuan website dalam menyampaikan berbagai macam format informasi seperti gambar, video, musik, animasi serta dapat terhubung dengan berbagai macam sosial media, diharapkan perancangan ini mampu menjadi media alternatif dalam menyampaikan informasi tentang aksara Jawa.

Secara keseluruhan, dilihat dari hasil uji coba yang telah dilakukan dan respon yang didapatkan, website Hanacara ini baik untuk digunakan sebagai penunjang dalam proses belajar aksara Jawa. Baik itu digunakan oleh guru/pendidik sebagai materi pendukung kegiatan belajar mengajar pada mata pelajaran Muatan Lokal, atau digunakan oleh para siswa sebagai sumber informasi alternatif untuk mempelajari aksara Jawa.

Perancangan ini diharapkan dapat memberikan kebaruan dalam penyampaian informasi aksara Jawa dan mampu menyentil rasa keingintahuan dari penggunanya, sehingga website ini menjadi pintu bagi remaja maupun masyarakat luas pada umumnya untuk mengenal aksara Jawa. Hasil perancangan website aksara Jawa ini bukanlah akhir dari upaya pelestarian aksara Jawa. Masih banyak pengembangan format penyajian yang bisa dimanfaatkan. Website ini berfungsi sebagai database aksara Jawa yang memungkinkan untuk menghasilkan karya lain di masa depan dan juga bisa dikembangkan dengan aksara daerah lain yang ada di Indonesia. 


\section{DAFTAR PUSTAKA}

Ahmadi, M. (2002). Dari Hanacaraka Ke Sastra Macapat Dan Suluk. In Prosiding Seminar Akademik, Volume 2 (pp. 89-103).

Hakim, O. O. A. A., \& Purnama, B. E. (2012). Perancangan dan Implementasi Sistem Pembelajaran Aksara Jawa untuk SD Berbasis Multimedia Di SDN Bumirejo 02. Speed - Sentra Penelitian Engineering Dan Edukasi, 4(2).

Hambali, I., Sunarto, M. J. D., \& Sutanto, T. (2013). Rancang Bangun Aplikasi Pembelajaran Aksara Jawa Berbasis Android. Jurnal JSIKA, 2(2), 106-112.

Kusumohamidjojo, B. (2009). Filsafat Kebudayaan: Proses Realisasi Manusia. Yogyakarta \& Bandung: Jalasutra .

Molen, W. (1993). Javaans Schrift. Leiden: Vakgroep Talen en Cultuuren van Zuidoost.

Nielsen. (2017). The New Trend Among Indonesia's Netizens. US: The Nielsen Company.

Pettersson, R. (2002). Information Design: An Introduction. Amsterdam: The Netherlands.

Rustan, S. (2014). Huruf, Font dan Tipografi. Jakarta: Gramedia Pustaka Utama.

Sihombing, D. (2017). Tipografi dalam Desain Grafis. Jakarta: Gramedia Pustaka Utama. Tim Penyusun Pedoman Penulisan Aksara Jawa. (1997). Pedoman Penulisan Aksara jawa. Yogyakarta: Yayasan Pustaka Nusatama.

Widyatmoko, F., Sanusi, M., Lumenta, N. H., \& Sungatno. (2010). Aksara-Aksara Nusantara. Yogyakarta: ZAT Publishing.

Yayasan Harapan Kita. (1997). Indonesia Indah: Aksara. Jakarta: PNRI.

Yogananti, A. F. (2015). Pengaruh Psikologi Kombinasi Warna Dalam Website. ANDHARUPA: Jurnal Desain Komunikasi Visual \& Multimedia (Vol. 1). Universitas Dian Nuswantoro.

Yohanes, B. W., Robert, T., \& Nugroho, S. (2017). Sistem Penerjemah Bahasa JawaAksara Jawa Berbasis Finite State Automata. Jurnal Nasional Teknik Elektro Dan Teknologi Informasi (JNTETI), 6(2). 